\title{
Translation as a Cultural Dialogue between the East and the West: Re-reading 'The Nobel Prize Acceptance Speech' by Tagore
}

Joyjit Ghosh

Professor, Department of English, Vidyasagar University, Midnapore, West Bengal, India. Email: joyjitghosh@mail.vidyasagar.ac.in

First published September 30, 2019

\begin{abstract}
Rabindranath Tagore was awarded the Nobel Prize for his English translation of Gitanjali in 1913. He was at once accepted by the Western people as one of their own poets. In the 'The Nobel Prize Acceptance Speech', Tagore, however, categorically stated that he must not accept the laurels as his 'individual share' because he represented the East and it was the East in him that gave to the West. Tagore always believed in a cooperation of cultures across the world. He was certain that he belonged to an age which bore witness to the meeting of the East and the West. The present paper while making an analytical study of 'The Nobel Prize Acceptance Speech' will try to establish that the objective of Tagore's translation of Gitanjali into English was not merely to 'rekindle' the aesthetic delight which the poet once experienced during the composition of the work in Bengali but to create a space for a dialogue between two separate spheres of civilization - the East and the West.
\end{abstract}

Keywords: Culture, Dialogue, Meeting, Mission, Translation

'Thou hast made me known to friends whom I knew not.

Thou hast given me seats in homes not my own.

Thou hast brought the distant near and

made a brother of the stranger.'

\section{Gitanjali, $63^{1}$}

'I have felt the meeting of the East and the West in my own individual life. I belong to the latter end of the Nineteenth Century. And to our remote country in Bengal, when I was a boy, there came a voice from across the sea. I listened to it. It would be difficult to imagine what it meant for me in those days.'

$$
\text { "Meeting of the East and the West" }
$$

'I say that a poet's mission is to attract the voice which is yet inaudible in the air; to inspire faith in the dream which is unfulfilled; to bring the earliest tidings of the unborn flower to a sceptic world.'

$$
\text { “To My Hosts"3 }
$$

Tagore received the Nobel Prize for his English translation of Gitanjali in 1913. This phenomenal achievement of Tagore drew the wide attention of the West to the writings of one who represented the East. From the Evening Post, New York dated 13 November 1913, we come to know that it was 'the first time on record that this prize has been given to anybody but a white person'. And in Interocean, Chicago dated 17 November 1913, we read, 'His name is scarcely known as yet

(c) AesthetixMS 2019. This Open Access article is published under a Creative Commons Attribution Non-Commercial 4.0 International License (http://creativecommons.org/licenses/by-nc/4.o/), which permits non-commercial re-use, distribution, and reproduction in any medium, provided the original work is properly cited. For citation use the DOI. For commercial re-use, please contact editor@rupkatha.com. 
to occidental readers. ... A recent translation of some of his poems into English by himself gives some idea of the reasons for his admission to the company which includes such distinguished names as Sully-Prudhomme, Mommsen, Bjornson, Sinkiewicz, Carducci, Kipling, Heyse, Maeterlinck and Hauptmann'. The Daily Mail stated, 'It is something new in our Imperial history to get great literature in our own tongue from the East', and made a glowing forecast that 'the poet, at the age of fifty-two will find his fame shining in the West as it has . . shone in the East'. ${ }^{4}$ In 'The Nobel Prize Acceptance Speech' delivered in 1921, Tagore categorically stated that he must not accept the accolades conferred upon him as his 'individual share' and significantly added, 'It is the East in me, which gave to the West'. ${ }^{5}$ In the present paper I would like to make an analytical study of Tagore's acceptance speech of the Nobel Prize with a view to showing that the purpose of the author's own translation of Gitanjali into English was to create a space for a cultural dialogue between the East and the West.

Tagore was a copious translator. He translated the poems by Moore, Burns, Byron, Shelley, Swinburne, Eliot and many other English poets into Bengali. Among his translations of other European poets mention must be made of the poems by Dante, Petrarch and Haine. Tagore translated the poems of Tukaram and Kabir, and many slokas from Sanghita and Upanishad as well. Sujit kumar Mandal in his Preface to Bideshi Phuler Guchchha rightly observes that Tagore accepted the East by translating from poems written in various non-Indian languages into English as well as represented the East to the West by translating his own poetry into English. ${ }^{6}$

Regarding the background of the translation of Gitanjali Tagore wrote in a letter from London (dated 6 May 1913) to Indira Devi Chaudhurani:

You may wonder why such a demanding task occurred to me in my enfeebled state - but I assure you it was not done out of some crazy bravado. It was just that I knew I had started a festival of poetic delight in my mind once before, fanned by the zephyr of my emotions, and so now I felt an urge to rekindle it through the medium of a foreign language. ${ }^{7}$

So translating Gitanjali into 'a foreign language' was not a reckless venture to Tagore. By his own admission, he wanted to 'rekindle' the aesthetic enjoyment which he once experienced during the composition of the work in Bengali. Tagore was, however, aware of the 'pitfalls' of the English language. And time and again in his letters, addressed to the celebrated English poets of the time including W.B. Yeats and Ezra Pound, Tagore unequivocally stated that he was 'absolutely ignorant of the properties of your language'. ${ }^{8}$ Even then the venture of translating the work brought him 'poetic delight'. 'The happiness associated with translating', according to Paul Ricoeur, 'is a gain when, tied to the loss of the linguistic absolute, it acknowledges the difference between adequacy and equivalence, equivalence without adequacy'. The translator 'acknowledges and assumes the irreducibility of the pair, the peculiar and the foreign', and finds his happiness in 'linguistic hospitality'. While discoursing on the concept of 'linguistic hospitality' Ricoeur says that it occurs 'where the pleasure of dwelling in the other's language is balanced by the pleasure of receiving the foreign word at home, in one's own welcoming house' (Ricoeur 11). Tagore's career as a translator bears evidence to this linguistic hospitality. The translation of Lord Alfred Tennyson's "Lilian" as "Nalini", to cite an instance, is a proof of receiving a foreign word 'in one's own welcoming house. ${ }^{9}$ On the other hand, when he translates his own work (Gitanjali) into English he derives an immense pleasure from 'dwelling in the other's language'. In a letter addressed to Edward John Thompson on 18 November 1913 Tagore wrote that the Gitanjali poems were 'intimately personal' to him, and he strongly emphasized that the pleasure I have of polishing their English versions is of a different nature [from] that of an author revising his works 
for publication'. ${ }^{10}$ So the publication of the English translation of Gitanjali was not the poet's prime concern. And this is also reflected in 'The Nobel Prize Acceptance Speech':

After my Gitanjali poems had been written in Bengali I translated those poems into English, without having any desire to have them published, being diffident of my mastery of that language, but I had - the manuscript with me when I came out to the West. And you know that the British public, when these poems were put before them, and those who had the opportunity of reading them in manuscript before, approved of them. I was accepted, and the heart of the West opened without delay. (NPAS 294)

The acceptance of Gitanjali by the West certainly thrilled Tagore beyond measure. But he modestly declined to receive the award as an individual. He made it plain that it was the recognition of the East as 'the mother of spiritual Humanity' by the West particularly when 'the children of the West' turned their hungry and famished faces to the 'serene mother', the East (NPAS 295).

The Gitanjali, Tagore unequivocally expresses in the speech, captures the zeitgeist, the spirit of the age:

I am glad that I belong to this great time, this great age, and I am glad that I have done some work to give expression to this great age, when the East and the West are coming together. . . . They have got their invitation to meet each other and join hands in building up a new civilization and the great culture of the future. (NPAS 297)

Tagore always believed in the union of the East and the West and attached a huge importance to the cooperation of cultures across the world. He did never subscribe to the view of Kipling when the latter said, 'Never the twain shall meet'. "Tagore was fully convinced that 'the West has met the East' and this 'momentous meeting of humanity . . . must have in its heart some great emotional idea, generous and creative'. ${ }^{22}$ It is interesting to note that Harald Hjarne, Chairman of the Nobel Committee, in the 'Award Ceremony Speech' appreciated Tagore's poetry as 'truly universally human in character' and eloquently pointed out that 'the poet's motivation extends to the effort of reconciling two spheres of civilization widely separated, which above all is the characteristic mark of our present epoch and constitutes its most important task and problem'. ${ }^{13}$

Tagore was certain that through his writing he could convey an idea 'which belongs both to the East and the West' although it was rendered 'obscurely through the translation' (NPAS 298). The use of the word 'obscurely' at this point is quite significant. It certainly reveals the poet's sense of genuine humility as a translator. But, I believe, it goes beyond the question of mere humility. 'All translation', Richard Kearney observes, 'involves some aspect of dialogue between self and stranger'. Kearney thus clarifies his idea, 'Dialogue means just that, dia-legein, welcoming the difference' (Kearney xvii). While translating his Gitanjali Tagore accepted the 'difference' between the mode of expression in his mother tongue and that in English, the target language over which he confessed he did not have a proper command. He wrote to William Rothenstein on 4 April 1915, 'My translations are frankly prose - my aim is to make them simple with just a suggestion of rhythm to give them a touch of the lyric, avoiding all archaisms and poetical conventions $^{14}$. One may quote the opening lines of Gitanjali no.7 in this context:

My song has put off her adornments.

She has no pride of dress and decoration.

Ornaments would mar our union;

they would come between thee and me; 
their jingling would drown thy whispers. ${ }^{15}$

These lines may remind an informed reader of Yeats's "A Coat" where the poetic persona is ready to give his coat (symbolic of his song), 'Covered with embroideries / Out of old mythologies' to the 'fools', and proclaims that 'there's more enterprise / In walking naked'. ${ }^{6}$ What exactly Yeats suggests by the expression that there is 'more enterprise/In walking naked' is not very much clear. Perhaps he thinks of discarding an old and obsolete poetic tradition and embracing one that encourages an unpretentious voice. When we look at Tagore's lyric, we understand that the 'adornments' of his song most probably allude to the 'archaisms and poetical conventions' which he avoided in his translation of Gitanjali. Tagore most probably sensed that these 'ornaments' would alienate the Western readers and create an impediment in the path of their appreciation of his work.

In his much discussed essay "Reflections: Rethinking Translation" K. Satchidanandan raises a couple of questions regarding the hermeneutics of translation: 'Is translation domestic inscription or cross-cultural communication? Is translation an international community-building exercise, a passage to Utopia? Or is it the opposite, an exposition of linguistic and cultural difference?' ${ }^{17}$ When we brood on these questions with reference to Tagore's translation of Gitanjali, we feel that these questions have no easy answers. We may only say that Tagore never ignored the issue of 'linguistic and cultural difference' while translating his work into English, but translation was definitely a tool of 'cross-cultural communication' at his hand. Tagore was not confident of the merit of his own English translations, as has already been discussed. But he believed, as he wrote to Sturge Moore, that 'whatever is broadly human and deeply true can be safely shipped for distant times and remote countries'. ${ }^{18}$ Most probably Tagore alluded to translation through which writings of broad human sympathy could be 'shipped' from one country to another. At this point, we are reminded of Salman Rushdie's observation, 'The word "translation" comes, etymologically, from the Latin for "bearing across". Having been borne across the world, we are translated men. It is normally supposed that something always gets lost in translation; I cling, obstinately, to the notion that something can also be gained' (Rushdie 17). Rushdie does not throw light on that which can be 'gained' in the process of translation. With reference to Tagore's translation of Gitanjali we may say that the process of translation definitely involves an international camaraderie. Till the fag end of his life Tagore acknowledged the value of Yeats's 'literary comradeship' and expressed his profound indebtedness for the latter's help which he rendered to his poems 'in their perilous adventure of a foreign reincarnation'. ${ }^{19}$ The use of the word 'reincarnation' is certainly suggestive. At this point it would be worthwhile to quote the observation of Subhas Dasgupta:

Evidently, Tagore here distinguishes between 'translating' and 'rewriting', the former implying 'word for word transference' from one language to another, and the latter, sensefor-sense transference leading to the 're-birth' or 'reincarnation' of the original in the target language. ${ }^{20}$

To what extent W.B. Yeats extended his 'friendly hands' to the 'rebirth' of Gitanjali in English does not come under the purview of the present paper. We at this point only want to bring to the fore that Gitanjali in the poet's own translation greatly appealed to the Western sensibility. W.B. Yeats in his Introduction to Gitanjali wrote:

A whole people, a whole civilization, immeasurably strange to us, seems to have been taken up into this imagination; and yet we are not moved because of its strangeness, but because we have met our own image, as though we had walked in Rossetti's willow wood, or heard, perhaps for the first time in literature, our voice as in a dream. ${ }^{21}$ 
This is an eloquent appreciation of a fellow poet's achievement. Yeats's remark that in Gitanjali the Western readers have met their 'own image' seemed to fulfil Tagore's dream to 'unite the hearts of East and the West' as expressed in 'The Nobel Prize Acceptance Speech' (NPAS 298). Tagore believed that the feeling of animosity between the East and the West must come to an end. Because India had always championed the spirit of unity: 'This ideal of unity never rejects anything, any race, or any culture. It comprehends all . . ' (NPAS 298). In Tagore's philosophy, this unity is far from being political; it is rather profoundly spiritual in orientation. One may recall some poignant lines in "Pilgrimage to India" in this context:

No one knows at whose great call

Streams of humanity

In a mighty tide flowed who knows whence

To mingle in that sea.

Aryan and non-Aryan came,

Chinese, Dravidian

Scythian, Hun, Mughal, Pathan,

In body blent as one:

And now the West unfolds its doors,

The world bears bounty from its store -

Give and receive, merge and be merged:

None will excluded be

From India's ocean-shore of great humanity. ${ }^{22}$

Since time immemorial, India, in Tagore's poetic vision, thus welcomes all races and cultures to its 'ocean-shore of great humanity'. He proclaims that this 'great mission' (NPAS 299) of the country ('Give and receive, merge and be merged') is reflected in starting his University. Tagore concludes the 'Nobel Prize Acceptance Speech' by inviting the people of the whole world to come to India and make Visva-Bharati 'a common institution for the East and the West' (NPAS 300 ).

I would like to conclude my essay by stating that Tagore decided to translate Gitanjali into English not merely because English was (and is still) a language of 'high international visibility' ${ }^{23}$ but because he wanted to contribute 'its riches to the common stock of civilization'. Translation to Tagore was a collaborative act, a tool by which he wanted to join 'the two great hemispheres of the human world across the sea'. ${ }^{24}$ There is hardly any doubt that Tagore was immensely successful in his mission.

[This is a slightly revised version of the paper which was presented at the International Conference on 'Translation across Cultures: Dissolving Boundaries - Creating Harmony' organized by the Department of Humanities and Social Science, Jaypee Institute of Information Technology, Noida, Uttarpradesh during 4-6 October, 2018.]

\section{Notes:}

NPAC stands for 'The Nobel Prize Acceptance Speech'.

1. See the poem in Gitanjali: Song Offerings (A Collection of Prose Translations made by the author from the original Bengali manuscript). New Delhi: UBSPD in association with Visva- Bharati, Santiniketan, first pub. 2003, ninth rpt. 2006, p. 167. All subsequent references to Gitanjali are from this edition. 
2. See the essay in The English Writings of Rabindranath Tagore: Volume Three: A Miscellany, ed. Sisir Kumar Das, New Delhi: Sahitya Akademi, first pub. 1996, rpt. 2012, p. 631.

3. See the essay in The English Writings of Rabindranath Tagore: Volume Two: Plays, Stories, Essays, ed. Sisir Kumar Das, New Delhi: Sahitya Akademi, first pub. 1996, rpt. 2012, p. 594.

4. The news published in the Evening Post, Introcean and the Daily Mail are available in the last pages of Gitanjali: Song Offerings (UBSPD - Visva-Bharati edition).

5. 'The Nobel Prize Acceptance Speech' is available in the UBSPD - Visva-Bharati edition of Gitanjali: Song Offerings, pp. 291-300. The references to the Speech are given in parentheses in the body of the essay abbreviated as NPAS with page no/nos.

6. See the Preface by Sujit Kumar Mandal to Bideshi Fuler Guchchha: An annotated anthology of the poems translated by Rabindranath Tagore from various non-Indian languages into Bangla including the originals, ed. Sujit Kumar Mandal, Kolkata: Papyrus, 2011, p.17.

7. See the letter in Selected Letters of Rabindranath Tagore, ed. Krishna Dutta and Andrew Robinson, with a foreword by Amartya Sen, New Delhi: Cambridge UP, First South Asian Edition, 2005, pp. 117-120.

8. See the letter to Yeats in Selected Letters of Rabindranath Tagore, p.105. A letter addressed to Ezra Pound dated 5 January 1913 is also noteworthy here. Tagore wrote to Pound, 'I am not at all strong in my English grammar - please do not hesitate to make corrections when necessary' (p. 103).

9. See Bideshi Fuler Guchchha, pp. 148-49.

10. See the letter in Selected Letters of Rabindranath Tagore, p. 132.

11. See the essay "East and West" in The English Writings of Rabindranath Tagore: Volume Two: Plays, Stories, Essays, ed. Sisir Kumar Das, New Delhi: Sahitya Akademi, first pub. 1996, rpt. 2012, p. 536.

12. "East and West", p.532.

13. http://www.nobelprize.org/nobel_prizes/literature/laureates/1913/press.html

14. See the letter in Selected Letters of Rabindranath Tagore, p. 162.

15. See the poem in Gitanjali: Song Offerings, p.15.

16. See the poem in W. B. Yeats: The Major Works, edited with an Introduction and Notes by Edward Larrissy, Oxford UP, first pub. 1997, reissued 2008, p. 59.

17. In his seminal essay "Reflections: Rethinking Translation" K. Satchidanandan raises some other questions regarding the hermeneutics of translation: 'What is the position of translated literature within the literary polysystem? What are the shifts of cohesion and coherence in translation?'. The essay is available in http://www.jstor.org/stable/23343212.

18. See the letter to Sturge Moore in Selected Letters of Rabindranath Tagore, p. 146.

19. See Tagore's letter to William Rothstein in Selected Letters of Rabindranath Tagore, pp. 418-419

20. Subhas Dasgupta, “Tagore's Concept of Translation: A Critical Study”. It is one of the seminal essays on Tagore's translation. The essay is available in http://www.jstor.org/stable/23345972.

21. Yeats's Introduction to Gitanjali: Song Offerings is available in the UBSPD - Visva-Bharati edition, pp.261-67.

22. See "Pilgrimage to India" in Rabindranath Tagore: Selected Poems, General Editor, Sukanta Chaudhuri, Advisory Editor, Sankha Ghosh, Introduction by Sankha Ghosh, Notes by Sankha Ghosh and Sukanta Chaudhuri, New Delhi: Oxford UP jointly by Visva Bharati, first pub. 2004, fifth imp. 2012, pp. 200-202.

23. The expression is borrowed from Martin Muller, "What's in a Word? Problematizing Translation between Languages”. The essay is available in http://www.jstor.org/stable/40346027. 
24. While speaking on his 'delightful surprise' by the offer of the Nobel Prize from Sweden, Tagore wrote in "East and West" (pp.533-34):

As a recognition of individual merit it was of great value to me, no doubt; but it was the acknowledgement of the East as a collaborator with the Western continents, in contributing its riches to the common stock of civilization, which had the chief significance for the present age. It meant joining hands in comradeship by the two great hemispheres of the human world across the sea.

\section{References}

Dasgupta, Subhas. (2012). “Tagore's Concept of Translation: A Critical Study”. Indian Literature. 56. 3. (269) (May-June 2012), 132-144. Sahitya Akademi. Retrieved from http://www.jstor.org/stable/23345972 Kearney, Richard. (2006). "Introduction: Ricoeur's philosophy of translation”. In Paul Ricoeur, On Translation. Translated by Eileen Brennan. London and New York: Routledge. .

Mandal, Sujit Kumar. (2011). Preface. Bideshi Fuler Guchchha: An annotated anthology of the poems translated by Rabindranath Tagore from various non-Indian languages into Bangla including the originals.

Sujit Kumar Mandal (Ed.). Kolkata: Papyrus.

Ricoeur, Paul. (2006). On Translation. Translated by Eileen Brennan with an introduction by Richard Kearney. London and New York: Routledge.

Rushdie, Salman. (2010). "Imaginary Homelands". Essays and Criticism: 1981-1991.

London: Vintage Books.

Satchidanandan, K. (2001). "Reflections: Rethinking Translation”. Indian Literature. 45.1. (201) (Jan-Feb, 2001), 5-8. Sahitya Akademi. Retrieved from http://www.jstor.org/stable/23343212.

Tagore, Rabindranath. (2006). Gitanjali: Song Offerings (A Collection of Prose Translations made by the author from the original Bengali manuscript). New Delhi: UBSPD in association with Visva- Bharati, Santiniketan.

--- (2006). “The Nobel Prize Acceptance Speech”. Gitanjali: Song Offerings (A Collection of Prose

Translations made by the author from the original Bengali manuscript). New Delhi: UBSPD in association with Visva- Bharati, Santiniketan, 291-300.

--- (2012) "Pilgrimage to India" in Rabindranath Tagore: Selected Poems. Sukanta Chaudhuri (Ed.),

Advisory Editor, Sankha Ghosh, Introduction by Sankha Ghosh, Notes by Sankha Ghosh and Sukanta Chaudhuri. New Delhi: Oxford UP jointly by Visva Bharati.

--- (2012) "East and West". The English Writings of Rabindranath Tagore: Volume Two:

Plays, Stories, Essays. Sisir Kumar Das (Ed.) New Delhi: Sahitya Akademi.

--- (2012) “To My Hosts”. The English Writings of Rabindranath Tagore: Volume Two:

Plays, Stories, Essays. Sisir Kumar Das (Ed.) New Delhi: Sahitya Akademi.

--- (2012) "Meeting of the East and the West", The English Writings of Rabindranath Tagore:

Volume Three: A Miscellany. Sisir Kumar Das (Ed.) New Delhi: Sahitya Akademi.

--- (2005). Selected Letters of Rabindranath Tagore. Krishna Dutta and Andrew Robinson (Eds.)

with a foreword by Amartya Sen. New Delhi: Cambridge UP, First South Asian Edition.

Yeats, W.B. (1997) W. B. Yeats: The Major Works. Edward Larrissy (Ed.) with an Introduction and Notes. New Delhi: Oxford UP.

Yeats, W.B. (2006) Introduction. Gitanjali: Song Offerings (A Collection of Prose Translations made by the author from the original Bengali manuscript). New Delhi: UBSPD in association with Visva- Bharati, Santiniketan, 261-267. 


\section{Author's bio-note:}

Dr Joyjit Ghosh is Professor, Department of English, Vidyasagar University, Midnapore, West Bengal, India. The areas of his interest include Animal Studies, Translation Studies, Bengali Dalit Literature and Indian English Literature. Since the early 1990s Dr Ghosh is a researcher in the field of D.H. Lawrence Studies. His book Imaging D.H. Lawrence: His Mind and Art in Letters (New Delhi: Authorspress, 2012) was reviewed by Susan Reid in the D.H. Lawrence Society Newsletter (No. 96). His article entitled "The Last Poems of D.H. Lawrence: Poetry of the Eternal Present" was published in Etudes Lawrenciennes, a French peer-reviewed journal (Issue No. 48) in 2017. Dr Ghosh frequently attends national/international level conferences. In the month of April this year he presented a paper titled "The Face of the Other: Reading a Selection of Animal Poems by D.H. Lawrence" at the $33^{\text {rd }}$ International D.H. Lawrence Conference held at Paris Nanterre University. 